\title{
Collaboration in mathematics: Taking a sociocultural perspective
}

\author{
Roberta Hunter, Massey University (New Zealand) \\ Marta Civil, The University of Arizona (USA)
}

\begin{abstract}
The importance of learners collaborating to construct deep mathematical understandings has been increasingly recognized in research and practice in recent times. In this paper we draw on a sociocultural perspective to show how a situative strength-based approach can be usefully applied to highlight the different ways in which learners from backgrounds within collectivist traditions participate constructively in mathematical interactions. As a key equity issue, learners from backgrounds in collectivist traditions should have the opportunity to expand their repertoires of practice so that they can flexibly adapt to any learning context. The two cases presented, from two geographic regions, both illustrate the central role the concept of family has for these learners - 'familia' or 'whānau'- as a collective concept of individuals working together not as individuals but rather as one unit.
\end{abstract}

Keywords. Collaboration; sociocultural; strength-based; family; mathematics education.

Colaboración en matemáticas: Adoptando una perspectiva sociocultural

Resumen

Actualmente, tanto la investigación como la práctica reconocen la importancia de que los estudiantes colaboren para desarrollar una comprensión profunda de las matemáticas. En este artículo nos basamos en una perspectiva sociocultural para mostrar cómo un enfoque situacional centrado en las fortalezas se puede aplicar para resaltar las diferentes formas en las que los estudiantes con orígenes en tradiciones colectivistas participan de manera constructiva en interacciones matemáticas. Como un tema clave de equidad, los estudiantes con orígenes en tradiciones colectivistas deben tener la oportunidad de expandir sus repertorios de práctica para poder adaptarse de manera flexible a cualquier contexto de aprendizaje. Los dos casos presentados, basados en dos contextos geográficos, muestran el papel central del concepto de familia para estos estudiantes - familia' o 'whānau'- como concepto colectivo de individuos que trabajan juntos no como individuos sino como una unidad.

Palabras clave. Colaboración; sociocultural; centrado en fortalezas; familia; educación matemática.

\section{Introduction}

In this paper we draw on our research agendas in two different geographic contexts (New Zealand/Aotearoa and USA) to reflect on the concept of collaboration in learning mathematics. Our work is grounded on a sociocultural approach to the teaching and learning of mathematics in non-dominant communities. We take a situative strengthbased approach to illustrate how learners from backgrounds rooted in collectivist traditions develop mathematical understandings.

Recognition of the importance of all students participating in collaborative mathematics discussions and engaging actively in the reasoning of others has gained increased attention over the past decade. Educators, researchers, and policy makers all acknowledge the role explaining and justifying mathematical arguments has on students co-constructing rich and deep understandings (Civil, 2014; Franke et al., 2015). Here, the focus of collaborative mathematical activity is placed on co-construction of 
collective understandings which suggests need for student interdependence in contributing individual and shared knowledge, strengths, and perspectives (Calor et al., 2019; Kaendler, Wiedmann, Rummel, \& Spada, 2015). However, we know that it is a simplistic view to suggest that through interactive collaboration all students will automatically construct deep mathematical understandings. There are a range of other factors which need to be considered including close examination of what it means for different students to participate in equitable ways to collaborative mathematics discussions. In this paper we use a sociocultural lens to examine and explore the idea of collaboration when learning and doing mathematics. What we aim to illustrate is how different and diverse learners from collectivist societies draw on their ways of knowing and being to collaboratively co-construct mathematical understandings.

\section{Background and theoretical framework}

Equity is at the heart of the many factors which support collaborative coconstruction of rich mathematical understandings. In referring to equity we draw on the definition proffered by Esmonde (2012) in which she outlines it as the "fair distribution of opportunities to learn, where situated and sociocultural theories of learning are brought to bear on the question of what constitutes an opportunity to learn" (p. 52). Esmonde links the term fair to notions of justice rather than equality. In taking this position, our goal is to reflect on what different forms of interactive collaboration may provide or preclude students with opportunities to learn mathematics, in ways that are just and fair. In doing so, we suggest that it is time that we consider the proliferation of different ways promoted for students to participate in classroom interactions which have emerged in the literature (e.g. Complex instruction in the USA and Exploratory talk in the UK) in the last two decades and think about how particular groups of students are served (or not) by these approaches. We question whether applying the same specific forms of interactions is appropriate for all learners, and whether by doing so assumptions are made that all groups of learners are the same. Furthermore, does this not also assume that what works for one group of learners can and should work for a different group of learners no matter what their social and cultural contexts might be?

Despite a common populist belief that mathematics classrooms are culturally neutral, this has been under dispute for numerous decades. Many theorists (e.g. Covarrubias, Herrmann, \& Fryberg, 2016; Phillips, 1983; Rogoff et al., 2017) caution the role education institutions take in reinforcing the values and beliefs of the dominant cultural groups. Rogoff and her colleagues explain how over time diverse communities who experience most of their education within the dominant cultural groups in Western world settings may assume that the learning, collaboration, and interaction patterns experienced within this setting are what is 'normal'. Similarly, these researchers suggest that well-meaning groups (e.g. policy makers, educators, researchers) also take as normal the practices they have experienced within this education system because of their limited knowledge of others outside the dominant group. The resulting deficit views of the differences are applied within non-dominant cultural groups with assumptions made that there is only one way to 'fix these problems' through interventions which are aimed to fill the mathematical gapped landscape (Faulkner, Marshall, \& Stiff, 2019).

In this paper, we draw on a sociocultural and situative frame within a strength-based focus rather than a subtractive view (Valenzuela, 1999). Within the subtractive model assumptions are made which suggest that the dominant way is the only way and as a result the cultural and language backgrounds of non-dominant students are perceived a problem rather than a resource. This causes some communities to adopt ways of 
knowing and being of the dominant cultural group rather than maintaining and using their own other familiar and successful ways. Within this model there are subtle messages around what it means to be normatively an appropriate person or self within specific contexts including the school and mathematics classroom (Markus \& Kitayama, 1991; Stephens, Townsend, Markhus, \& Phillips, 2012). As Markus and Kitayama explain, the Western world dominant cultural group promotes concepts of self as independent and self-reliant. Notions of self as an individual sharply contrast with that of those groups within collectivist societies. Within these groups concepts of self are seen within interconnected and interdependent relationships. This is evidenced by Hunter and Hunter (2018) who describe the dissonance and the discomfit the Pāsifika students in their studies experienced when placed in mathematics ability groups where individualism and competitiveness were the norm of the dominant group. Although these Pāsifika students who came from more interdependent relational communities appeared to accept the norms of self which belonged to the dominant cultural group within Aotearoa/New Zealand, when interviewed they expressed views which showed that these had caused a negative sense of self and subsequent loss of cultural identity.

Taking a strength-based approach model is our way forward. This is the premise in the funds of knowledge for teaching project (González, Moll, \& Amanti, 2005), which informs our work. Within that project the focus is placed on building from and on the communities' cultural strengths. Building on their prior knowledge allows those groups marginalized by a dominant Western world view to extend their repertoires of practice (Gutiérrez \& Rogoff, 2003; Rogoff et al., 2017). Rogoff (2003) suggests that by extending from known repertoires of practices within their own and community history these individuals will be supported to become more adept at selecting which repertoire is appropriate to any context. This allows them to be flexible and adaptive to the many repertoires of practice they have been exposed to including those which relate more to the dominant cultural group but can also select those within their own close community.

There are many cultural differences which have been observed of children from a collectivist world view, working together in collaborative ways. These include some very young children within family groups in the home taking the initiative in contributing to core aspects of the functioning of family endeavors (e.g. cleaning, food preparation and economic activity). Civil and Andrade (2002) describe the case of Alberto, a Mexican immigrant child in the USA, who did not seem engaged with mathematics in school. Through a home visit, the teacher found out that back in Mexico, Alberto had helped his family's bakery by delivering orders to customers after school. He was engaged in all aspects of this activity, keeping track of orders and managing money. As Alberto's mother shared her account, we could see her pride in her child's accomplishments. Civil (2016) wonders about how competence is defined in school settings versus community/home settings.

Other cultural differences observed include ways in which different groups of children approach activities which involve them thinking and working together. Rogoff and colleagues (2017) describe the sophisticated levels of collaboration observed in many studies in which "Indigenous-heritage backgrounds of the Americas" (p. 880) think together drawing on each other's ideas and direction to advance their collective agenda. They achieved this without need for discussion through their close attention to others' efforts and activity. These researchers describe how these actions supported them to flexibly and seamlessly align their own actions towards their end goal almost as one organism. Rogoff et al. contrast these learners with those middle-class European American children. They describe how these students worked as individuals within the 
confines of a group, tasks were individually allocated, and only single individuals attended to the task and conflict emerged over acceptance of individual ideas.

Similar patterns of sophisticated forms of collaboration are seen within Indigenousheritage Māori and Pāsifika learners in Aotearoa/New Zealand and the Pacific Islands. Jenkins and Harte (2011) describe the ways in which young Māori children learn, through close watching at the knees of their parents and other whānau (wider family and community) members, the respectful ways to engage in interactions in hui (meetings). Tamarua (2006) describes how young Māori learning occurs within what is described as a tuakana-teina (older/younger siblings) collaborative reciprocal relationship. The tuakana is responsible for and inducts the teina into family roles which support the wider whānau including many household chores. The pattern is similar for Indigenous-heritage Pāsifika nations children. Fletcher et al. (2009), and Alefaio (2019) show the importance of collaborative interactions and reciprocal responsibilities within Pāsifika families. Value placed on respect of elders underpins careful listening and watching as younger members of the community adopt patterns of interactions they are observing. Alefaio described how Samoan children as young as five or six years automatically assumed responsibility for younger siblings; this included reading to them and teaching them how to do chores. Tamarua, and Fletcher et al. draw on student voice to explain how this group of students want to work as one within their schooling rather than as individuals.

Having strong relationships, mutual trust, and respect is fundamental for all children to actively participate in collaborative co-construction of mathematical reasoning. In our studies (e.g. Civil \& Hunter, 2015; Hunter \& Hunter, 2017) we show how Pāsifika values and beliefs are premised within a collectivist focus in which students talk about the importance of working as a family within what Moll (2005) described as confianza (mutual trust) and respect. These values support ways for natural agreement and disagreement and humor as shown by Civil and Hunter when engaging with Mexican American and Māori and Pāsifika communities. These researchers showed how social chat and good-humored laughter and teasing emerged when tensions arose were important to developing a safe mathematical learning environment in a similar way to what happens within many Mexican American and Māori and Pāsifika families. In other situations, within dominant cultural groups within a Western-world view, disagreement and laughter may be seen as negative interactions within the mathematics classroom.

Constructing classroom environments that support all students to engage in productive mathematical discourse has been the focus of considerable research. Set within a sociocultural frame the work of Mercer and his colleagues (e.g. Fernández, Wegerif, Mercer, \& Rojas-Drummond, 2001; Mercer, 2000) has focused on developing exploratory talk as a means to have all students engage critically in constructive ways. These researchers describe two other less positive ways students engage in talking and arguing together. These, they term disputational and cumulative talk. Disputational talk is characterized by disagreement and competitive assertions while cumulative talk consists of uncritical repetitive responses. Although this applied research is set within a sociocultural and situated perspective much of the research related to it has been in British schools positioned in the dominant cultural group. If we shift the lens from the dominant cultural group set within an individualistic perspective towards that held within the collectivist world view, we question whether we would continue to consider that these forms of talk hold true. Another example is the considerable research around the use of complex instruction (e.g. Cohen \& Lotan, 1998; Featherstone et al., 2011) in mathematics classrooms. Complex instruction incorporates pedagogical strategies to address inequities in participation when students work in heterogenous groupings. 
Although there are many sound aspects of the work, one suggested strategy includes the creation of individual roles (e.g. material organizer, timekeeper, questioner). We question the allocation of individual roles within the collectivist perspective as conflicting with the Pāsifika values and beliefs (Hunter \& Hunter, 2017; 2018).

\section{Method}

This paper is mostly a reflection based on our long research trajectory looking at the participation of non-dominant students in the mathematics classroom within a sociocultural lens. Thus, we do not report on particular studies here. In the next sections, we present two cases, one from each geographic context to illustrate our points.

The case from New Zealand comes from a set of mathematics lessons in which the students worked collaboratively to solve challenging mathematics problems. The participants were all Māori or Pāsifika nations students although Pāsifika nations students were the dominant group. They all attended an urban school in a high poverty area, and were aged between 10-13 years. The focus is on the part of the lesson in which the students worked in small groups to develop a group response to share with the larger class group. The first author reviewed the video records and selected those which showed groups working together with attributes both researchers had agreed upon. After further discussion, selection was made of one video record which represented common forms of collaboration we had noted as we viewed group interactions.

The case from Arizona, USA comes from a series of mathematics workshops for parents and children at an elementary school in a Mexican American neighborhood, with almost $90 \%$ of students classified as Hispanic (mostly Mexican origin) and also almost $90 \%$ of students from low-income families. The second author made an initial selection of video clips of interactions between parents and children in the workshops with a focus on the attributes both authors have noticed in collaborations when doing mathematics (e.g. use of humor, non-competitiveness, trust, support). After discussion of the clips with the first author, we chose one clip centered on a game to practice multiplication, as representative of the nature of the collaboration documented across multiple examples of mathematical interactions between parents and children in these workshops.

In the next sections we draw on two cases of students in New Zealand and Arizona, to illustrate how they have drawn on different repertoires of practice to flexibly construct mathematical knowledge. We show how the repertoires of practices are embedded in a strength-based environment which allows them access to construct learnings.

\section{The case of Māori and Pāsifika nations students in Aotearoa/New Zealand}

Māori are indigenous to Aotearoa and Pāsifika nations people are their first cousins. Pāsifika (known also as Pāsefika, Pacifica) is a term developed in Aotearoa/ New Zealand and used to collectively describe various groupings descendants of Pacific nations people. They span first to fifth generation born in Aotearoa/New Zealand. The groupings have many traditions and languages and cannot be considered as homogenous (Anae et al., 2001). Across both the Māori and Pāsifika nations communities, however, there are rich threads of common beliefs and values which support a strong emphasis on whānau (family) and which includes a wider grouping in the community than that of the individual family within a dominant Western world view.

Within the community, rich whānau (family) oriented activities are maintained. Large families are closely interwoven in their daily lives through attending Pāsifika nations churches, supporting family through economic activity (e.g. making food and 
other things to sell at the local market) and participating in other traditional family activities (e.g. family celebrations, meetings, sports events). The teacher in the case was an experienced teacher and had participated for five years in a research-evidenced professional learning and development programme called Developing Mathematical Inquiry communities (DMIC) (for further information, see Hunter \& Hunter, 2017; 2018). Within DMIC best practice for mathematical teaching and learning is coupled with culturally sustaining practices. However, although many students spoke a home language at times at school the lesson and problem were presented in English. But, in the teacher facilitated discussions careful attention was given to correct pronunciation of the Tonga words and their meaning.

The problem that the group in the classroom was working on is:

A group of Tongan mamas are making ta'ovala (ceremonial costumes). It takes them 5 hours to weave 9 ta'ovala. How long will it take them to weave 12 ta'ovala?

The teacher explained that he had selected this task as appropriate for his learners because he had a number of Tongan students in the group who would be able to explain the cultural relevance of ta'ovala and the ways in which the mamas all worked together as one to complete them. When he launched the task, he drew on student voice to explain when these were worn. He then questioned how they were made. Different students explained how ta'ovala were made by hand over a period and done in groups. The teacher built on student responses to establish the group norms:

Teacher: Yes, it takes a long time, but people do it together. What about when you work in a group, how does that help you?

The students responded with ideas which related to them sharing ideas, sharing different ways of solving so everyone understood. Focusing on constructing understanding the teacher then stated:

Teacher: So, everyone understands. So, if you think back to making ta'ovala it might be hard but experienced people are there to help you, so you all end up thinking together.

Through his actions the teacher provided the students with a normative sense of self as interconnected and interdependent. He used the making of a cultural artefact, which is well known by Tongan students within their local community history, to provide them with an alternative repertoire of practice than what these students normally experienced in schools in Aotearoa/New Zealand. Through such actions Rogoff et al. (2017) suggest that students learn to select and flexibly and adaptively shift between repertoires.

In this next piece of data, we report on one group of four students as they worked together independent of the teacher. They had a large sheet of paper and Student 1 picked up the pen and wrote 5:9.

Student 2: So, it is five hours and nine ta'ovala. Then twelve. [Student 1 writes 12 under the 9 , and ? under the 5]

Student 4: So, how do we get that? [pointing at the ?]

Student 2: Five divided by three. [records 5:3]

All the students were following closely, and they all nodded together. Then Student 4 picked up the pen and wrote Ta'ovala takes ??? hours. Then he wrote $3 \times 4=$ ?? hours.

Student 2: So, we know that half of five is two point five.

Student 3: But, a half of two point five is tricky. 
Student 1: I know it is one something.

Student 4 picked up the pen and wrote 1.6. There was a pause as all the group thought about it.

Student 2: Shall we add the three one point six?

As the students constructed the mathematical explanation the pen and verbal explanations moved interchangeable and seamlessly between all members of the group. Each member attended closely and added on to what another had contributed. Their collective actions, close attention to every other member's utterance, and their use of the word "we" indicates that they considered themselves as one and were working collectively towards a shared goal. These actions replicate the ways in which Fletcher and colleagues (2009) and Alefaio (2019) describe them learning within their home contexts. Then the interactions changed when a student asked:

Student 1: But isn't it one point six, six, six, six, six and so on? [he laughs]

There were a few minutes of joking talk between all the students then the other three all laughed and said together:

Students: Yes, and so on and on and on. [more laughter]

Student 1: Just to update, I will write five divided by three equals one point six, six, six, six, six, six and so on. [writes as he says]

The four together then said with laughter:

Students: Okay, so one point six dot, dot, dot, dot, times four equals six point four.

The use of laughter and small talk reduced the tension when the student challenged their collective thinking. It gave them all space to reflect and respond and move forward with their collective mathematical explanation. Within this space it also supported others to evaluate and question the explanation they had constructed.

Student 2: But we have to find hours and minutes. [laughs]

Student 3: The one point six, six, six, six, six is hours...

Student 4: And minutes.

Student 2 recorded $1 \mathrm{hr}=60$ minutes. Student 4 then recorded 60:3=20, then 2 hours $=120 \mathrm{~m}$. All members of the group nodded in agreement and then Student 1 wrote $120: 3=40$ and recorded $1.40: 3$ above $5: 9$ as she said:

Student 1: One hour plus forty minutes. So, what were we thinking there? [points at 1.666666]

The discussion stopped here as they returned to a larger class discussion.

Evident in the findings is the way in which these four students drew upon each other's reasoning to further their individual and collective understandings in a natural and adaptive way. On the way to constructing a joint mathematical explanation, they all watched and listened carefully as the pen moved freely between them and they seamlessly appeared to finish off or record each other's ideas. Watching them interact it would be difficult to provide evidence of them using what Mercer (2000) described as exploratory talk and their effortless adding of ideas if analysed within a more individualized frame might be described as cumulative and their jokes and laughter as disputational talk. However, they were drawing from and building on their own cultural 
strengths which Jenkins and Harte (2011) describe as learnt at the knees of their elders within a whānau (family). In doing so, it was important to interpret their close following of each other's actions and interwoven additions within a situated perspective to be able to see their use of exploratory reasoning.

Following the lesson, the students were interviewed about how they felt about working together.

Student 1: It is good because we share our ideas together and we depend upon each other. But you can question too.

Student 2: It is good to be confident because they depend on you. But if you get it wrong that's okay because we are altogether.

Student 4: We just trust in ourselves and believe we can do it, and I like it because we share our ideas and help each other and ask questions and be confused and that is all right.

The students all outlined similar views related to how they considered that in working together they were interdependent and interrelated. While they were personally accountable for themselves, at the same time they were accountable to each other. This involved not just building on each other's' reasoning but also asking questions and working together through misconceptions and confusion. Strong relationships, respect, and reciprocity they experienced within their collectivist history allowed them to develop a repertoire of practice which was founded on mutual trust and had no need for such interventions as allocation of roles as suggested by Featherstone et al. (2011).

\section{The case of families of Mexican origin in Arizona, USA}

While in Civil and Hunter (2015) we looked at work with students in the classroom in the two contexts, New Zealand and the USA, for this paper we move away from the classroom for the case of Arizona and focus on the work with parents and children in mathematics workshops at a school. This choice is intentional as we want to stress a basic context in a sociocultural approach to learning, which is the family context. Families engage in mathematical activities in settings such as out-of-school activities and parents helping children with homework, which is directly related to school mathematics. Our context of mathematics workshops for families provides an informal setting though still related to in-school mathematics. In a sense the workshops create hybrid spaces (Gutiérrez et al., 1999), blurring the boundaries between in-school and out-of-school learning. In the workshops there are elements that point to a hybrid space, in particular in the use of language, as participants often move back and forth between English and Spanish, in contrast with the school (where English is dominant) or the home (where Spanish is dominant); another aspect of hybridity has to do with the roles of expertise, as in the workshops parents and children often move fluidly between expert and novice; in some cases the parent acts as the expert guiding the child's learning; while in others, the child is teaching the parent a different approach to do a problem.

The workshop we have chosen for this paper was on games that families can play to support students' learning of multiplication. One of the games, "card on head", consists of three people: two players and the person in charge of calling out the product. Each player puts a card on their forehead so that they can see the other person's card but not theirs. The "caller" gives the product of the two cards and the players have to determine what card they are holding. So, for example, player one has "six", player two has "three", caller would say "eighteen". Player one sees that one of the factors is three (the card on player two's forehead) and would then say that their card is six. In what follows we 
center on two siblings (Kyle and Carla) and their mother. Kyle was a fifth grader (about 10 years old); Carla, a seventh grader (about 12 years old). The activity took place two months into the school year and was intended for the younger students to practice multiplication. The game is set up in a playful manner where the "caller" says "saluden" ("say hi") and the players put the cards on their forehead. Let's look at the first two rounds of this game with this family.

In round one, Kyle has nine; Carla has one; the mother says nine. Carla right away says one; Kyle hears someone in another group saying eight and he says "yes, eight." The mother starts laughing in a good-natured way, and Kyle is also laughing. Carla smiles. The mom says, "it's the multiplication table." Kyle says "ah" and then looks at his card. In round two, Kyle has five; Carla has six; the mother says "thirty" (laughing) and then the following exchange (in Spanish) follows:

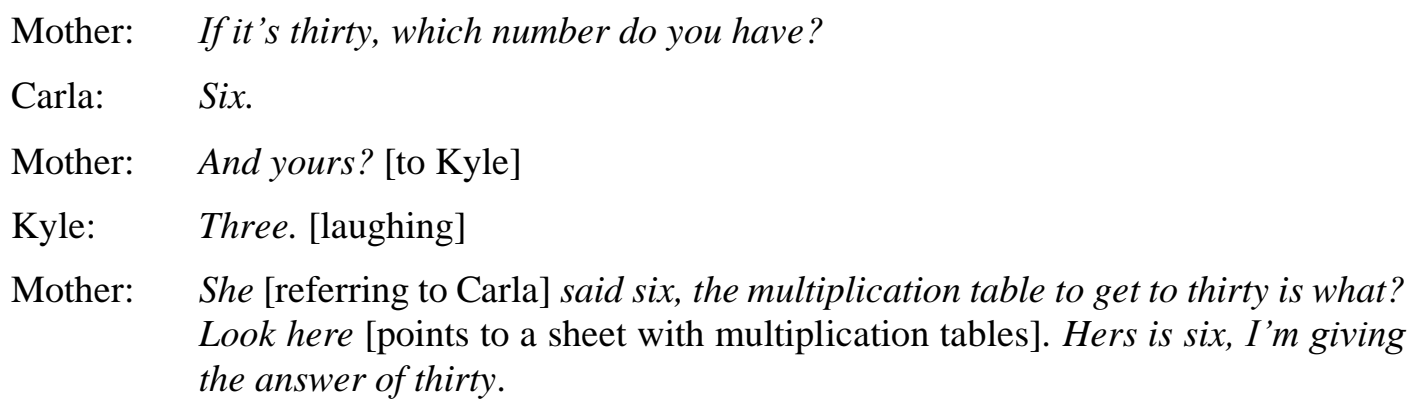

Kyle: $\quad$ Which is the table?

Mother: Well, the six table.

Kyle: $\quad$ The six ... five, five, mine is five. [laughing]

Mother: Aaaaah [laughing too]

Through the first few rounds, Kyle is becoming familiar with the goal of the game. For example, in round three, the product is 36 and Carla's card is four. Kyle instead of saying nine for his card, says six and then when he finally gets nine with help from his mother, he says "but look, six times six is thirty-six." The mother then says, "it's the four table." At this point, Kyle says "ohhh", the mother laughs and Carla smiles. After that, Kyle gets the goal of the game and starts getting his card. For example, in round five, Kyle has eight, Carla has six, and the mother says forty-eight for the product:

Mother: Which number does she have?

Kyle: [who of course can see his sister's number] Six.

Carla: Six. [at the same time as Kyle says "six"]

Kyle: $\quad$ I have eight.

Mother: $\quad$ Ok, you see. [Kyle and mother are laughing]

Kyle, Carla and their mother play the game for about 15 minutes. For some rounds, Kyle uses the sheet with the multiplication tables but for some he does not. For example, for an early one where the product is 70 and Carla's card was seven, Kyle looked at the multiplication table; but for a later round with a product of 30 and Carla's card three, Kyle quickly says ten for his card. Kyle's and his mom's laughter dominate the game. Carla does not laugh but smiles from time to time. At no moment are laughter and smiles seen as making fun of someone for "not knowing" (Kyle in this case). On the contrary, they are seen as affective markers in which the three family members partake. 
Carla is an active participant throughout the game. She does not give away her brother's card, which is something that may happen in other siblings' situation where the older sibling takes over the game. Carla keeps the card on her forehead for the duration of each round, while her brother is thinking about what his card is. She is patient and supportive of her brother's attempts to understand the game. The mother guides her son in the game till it clicks. She does not give Kyle the answer but shows him how to figure it out by looking at the corresponding multiplication table. For the duration of the game, the three family members are engaged and the older ones are supporting the boy's learning. Laughter and joy mark the whole interaction in a non-competitive atmosphere. The game format probably facilitates the relaxed engagement, but one could imagine the mother taking a direct teaching approach to meet the goal of the game, which is for the child to practice the multiplication facts; or a competitive approach where the sister guesses her card and ends the turn since she is done. None of this happens here. The family is engaged in each turn of the game as a whole in a collaborative way along the lines of what Rogoff et al. (2017) describe as being the case with children of Indigenous origin. As these authors indicate, this collaborative approach differs from how middleclass children of European origin play games in the USA, where "Anglo pairs tended not to pay attention when they did not have the lead" (p. 880).

While this is only a brief example of one family's mathematical interaction, it has several of the characteristics we have seen across multiple examples of parents and children engaging together in mathematical activities. The laughter and relaxed atmosphere are key contributors to the goal to support Kyle's practicing the multiplication facts. The interaction shows a collaborative engagement where even when the expertise is clearly distributed, as in this case where Kyle is the learner and Carla and her mother are the more knowledgeable ones, the interaction is marked by a sense of "we are in this together."

\section{Conclusion and implications}

Equity was at the heart of this paper and so we drew on a sociocultural perspective to show different ways mathematical teaching and learning can take place for learners from non-dominant communities. We showed how applying a situative strength-based approach made visible how parents and teachers were able to support learners to flexibly select repertoires of practice which matched the learning contexts they were in. Rogoff et al. (2017) explain the importance of learners being able to expand their repertoires of practice through accessing both their prior knowledge of ways to interact and collaborate learnt within their home and community -ways which are often made invisible by those commonly used within the dominant world setting their formal mathematics learning takes place. Through adopting a situative lens what was evidenced in these two cases was the importance of attending to the learner's notions of self as situated within the dominant cultural world setting but able to draw on other ways of knowing and being.

In the first case in Aotearoa, the students had adopted a repertoire of practice in which they participated in mathematical learning, not as single, independent individuals but as an interrelated and interdependent organism in which they saw themselves as one. On interview the students voiced their sense of what they considered appropriate in their roles as they participated in the mathematical activity. Their sense of need for reciprocity and interdependence in mathematical activity contrasted sharply with what Markus and Kitayama (1991) describe as often a normalized sense of self within the more individualized dominant Western world settings. In both cases the use of humor was an important aspect of progressing mathematical learning. 
The case of Arizona is intended to bring attention to the importance of understanding family interactions around mathematics. The concept of family is particularly important in groups from collectivist traditions. As Rodríguez-Brown (2010) writes in reference to the meaning of familia for Latinos, "this term means that whatever is done in everyday life should benefit not only the individual but also the family.... The concept of familia implies responsibility and collaboration... The familia shares responsibility for a child's success or failure" (p. 351). Carla, Kyle, and their mother engage with the game together as a family to support Kyle's learning of multiplication facts.

What is evident from these findings is the need for teachers and other educators to have deep understandings related to learners who are not from the dominant cultural group. For equitable outcomes to occur they need to understand and appreciate their different learner's familiarity of experiences with cultural practices which have been recently constructed or are a part of their long-time history related to their local home and community context. This requires understanding interactions which differ from what is considered 'normal' within a dominant cultural world view. This includes ways in which these students use humor and small talk to reduce tensions and their close watching of each other's actions and the almost seamless continuation of mathematical reasoning. As Civil (2016) writes, "we need to gain a better understanding of the participation structures, particularly in non-dominant communities" (p. 56).

Although we have used cases of learners who come from more collectivist cultural groups and have explored how this may have influenced their patterns of participation, we acknowledge that as Rogoff (2003) cautions we are not over-simplifying the division between learners who are from collectivist and individualistic groups because the students we refer to have a foot in both worlds. What we have shown is that in both cases the learners had not assumed that the learning, collaboration and interaction patterns they experienced within their dominant Western world education were the only 'normal' ways to be -they were able to select other ways within the learning context. Furthermore, in the opening of this paper we signaled our own questioning around the use of different research programs designed to support productive mathematical interactions. A clear implication is that we need to take care with who, how and where these are applied.

\section{Acknowledgements}

We acknowledge and thank the New Zealand Ministry of Education for funding the first case and the U.S. National Science Foundation (ESI-0424983) for the support for the second case.

\section{References}

Alefaio, S. (2019). Samoan parental perceptions of early literacy practices at home and in the community for children transitioning from Aoga Amata to mainstream primary school. Auckland, New Zealand: Massey University.

Anae, M., Coxon, E., Mara, D., Wendt-Samu, T., \& Finau, C. (2001). Pāsifika education research guidelines. Wellington, New Zealand: Ministry of Education.

Calor, S., Dekker, R., van Drie, J., Zijlstra, B., \& Volmann, M. (2019). "Let us discuss math". Effects of shift-problem lessons on mathematical discussions and level raising in early algebra. Mathematics Education Research Journal, 32, 743-763.

Civil, M. (2014). Guest editorial: Musings around participation in the mathematics classroom. The Mathematics Educator, 23(2), 3-22. 
Civil, M. (2016). STEM learning research through a funds of knowledge lens. Cultural Studies of Science Education, 11(1), 41-59.

Civil, M., \& Andrade, R. (2002). Transitions between home and school mathematics: Rays of hope amidst the passing clouds. In G. de Abreu, A. J. Bishop, \& N. C. Presmeg (Eds.), Transitions between contexts of mathematical practices (pp. 149169). Boston, MA: Kluwer.

Civil, M., \& Hunter, R. (2015). Participation of non-dominant students in argumentation in the mathematics classroom. Intercultural Journal, 26(4), 296-312.

Cohen, E. G., \& Lotan, R. A. (Eds.) (1997). Working for equity in heterogeneous classrooms: Sociological theory in practice. New York: Teachers College Press.

Covarrubias, R., Herrmann, S. D., \& Fryberg, S. A. (2016). Affirming the interdependent self: Implications for Latino student performance. Basic and Applied Social Psychology, 38(1), 47-57.

Esmonde, I. (2012). Mathematics learning in groups: Analysing equity within an activity structure. In B. Herbel-Eisenman, J. Chopin, D. Wagner, \& D. Pimm (Eds.), Equity in discourse for mathematics education (pp. 51-67). New York: Springer.

Faulkner, V. N., Marshall, P. L., \& Stiff, L. V. (2019). The stories we tell: Math, race, bias and opportunity. London, England: Rowman \& Littlefield.

Featherstone, H., Crespo, S., Jilk, L., Oslund, J., Parks, A., \& Wood, M. (2011). Smarter together! Collaboration and equity in the elementary math classroom. Reston, VA: NCTM.

Fernández, M., Wegerif, R., Mercer, N., \& Rojas-Drummond, S. (2001). Reconceptualizing "scaffolding" and the zone of proximal development in the context of symmetrical collaborative learning. Journal of Classroom Interaction, $36(2), 40-54$.

Fletcher, J. O., Parkhill, F., \& Harris, C. (2011). Supporting young adolescent students from minority cultural groups who are underachieving in learning. Support for Learning, 26(3), 122-126.

Franke, M., Turrou, A., Webb, N., Ing, M., Wong, J., Shin, N., \& Fernandez, C. (2015). Student engagement with others' mathematical ideas: The role of teacher invitation and support moves. Elementary School Journal, 116(1), 126-148.

González, N., Moll, L. C., \& Amanti, C. (Eds.) (2005). Funds of knowledge: Theorizing practices in households, communities, and classroom. Mahwah, NJ: Erlbaum.

Gutiérrez, K. D., Baquedano-López, P., \& Tejeda, C. (1999). Rethinking diversity: Hybridity and hybrid language practices in the third space. Mind, Culture, and Activity: An International Journal, 6, 286-303.

Gutiérrez. K., \& Rogoff, B. (2003). Cultural ways of learning: Individual traits or repertoires of practice. Educational Researcher, 32(5), 19-25.

Hunter, R., \& Hunter, J. (2017). Opening the space for all students to engage in mathematical talk within collaborative inquiry and argumentation. In R. Hunter, M. Civil, B. Herbel-Eisenmann, N. Planas, \& D. Wagner (Eds.), Mathematical discourse that breaks barriers and creates space for marginalized learners. Rotterdam, Netherlands: Sense Publishers. 
Hunter, R., \& Hunter, J. (2018). Maintaining a cultural identity while constructing a mathematical disposition as a Pāsifika learner. In E. A. McKinley, \& L. Tuhiwai Smith (Eds.), Handbook of Indigenous Education (pp. 1-19). Dordrecht, Netherlands: Springer.

Jenkins, K., \& Harte, H. M. (2011). Traditional Māori parenting. An historical review of literature of traditional Māori child rearing practices in pre-European times. Auckland, New Zealand: Te Kahui Mana Ririki.

Kaendler, C., Wiedmann, M., Rummel, N., \& Spada, H. (2015). Teacher competencies for the implementation of collaborative learning in the classroom: a framework and research review. Educational Psychology Review, 27(3), 505-536.

Markus, H. R., \& Kitayama, S. (1991). Culture and the self: Implications for cognition, emotion and motivation. Psychology Review, 98, 224-253.

Mercer, N. (2000). Words and minds: How we use language to think together. London, England: Routledge.

Moll, L. C. (2005). Reflections and possibilities. In N. González, L. Moll, \& C. Amanti, C. (Eds.), Funds of knowledge: Theorizing practice in households, communities, and classrooms (pp. 275-287). Mahwah, NJ: Lawrence Erlbaum.

Phillips, S. (1983). The invisible culture. Prospect Heights, IL: Waveland.

Rodríguez-Brown, F. (2010). Latino families: Culture and schooling. In E. G. Murillo, Jr., S. A. Villenas, R. Trinidad Galván, J. Sánchez Muñoz, C. Martínez, \& M. Machado-Casas (Eds.), Handbook of Latinos and education: Theory, research, and practice (pp. 350-360). New York: Routledge.

Rogoff, B., (2003). The cultural nature of human development. New York: Oxford University Press.

Rogoff, B., Coppens, A., Alcalá, L., Aceves-Azuara, I., Ruvalcaba, O., López, A., \& Dayton, A. (2017). Noticing learners' strengths through cultural research. Perspectives on Psychological Science, 12(5), 876-888.

Stephens, N., Townsend, S., Markus, H., \& Phillips, L. (2012). A cultural mismatch: Independent cultural norms produce greater increases in cortisol, and more negative emotions among first-generation college students. Journal of Experimental Social Psychology, 48, 1389-1393.

Tamarua, L. T. (2006). Pathways to literacy and transitions to school: Enabling incorporation and developing awareness of literacy. Unpublished Doctoral Thesis, University of Auckland, New Zealand.

Valenzuela, A. (1999). Subtractive schooling: US-Mexican youth and the politics of caring. Albany, NY: State University of New York Press.

\section{Authors' contact details}

Roberta Hunter, Massey University (New Zealand).r.hunter@massey.ac.nz

Marta Civil, The University of Arizona (USA). civil@math.arizona.edu 


\title{
Collaboration in mathematics: Taking a sociocultural perspective
}

\author{
Roberta Hunter, Massey University \\ Marta Civil, The University of Arizona
}

The importance of learners collaborating to construct deep mathematical understandings has been increasingly recognized in research and practice in recent times. In this paper, we draw on a sociocultural and situative perspective to show how equitable opportunities to participate can be provided within a strength-based approach. As a key equity issue the importance of learners from backgrounds founded in collectivist traditions being able to expand their repertoires of practice so that they can flexibly adapt to any learning context was argued. The theoretical frame adopted in this paper supported our illustration of different repertoires of practice learners from backgrounds founded within collectivist traditions had available and could select to participate constructively in mathematical interactions. Two cases were presented, from two different geographic regions. Both cases illustrated the central role the concept of family has for these learners -that is as familia or whanau- a collective concept of individuals working together not as single independent and individual units but rather as one interrelated and interdependent unit or organism. In the Aotearoa case, the way in which the students interacted as they constructed rich mathematical reasoning almost as a single organism, places in question assumptions about what is normatively accepted within a dominant world perspective as how learners should participate in collaborative interactions. Likewise, across both cases the different ways the role of humor is considered. The case of Tucson brings attention to the importance of understanding different family interactions around mathematics. In summary, what both cases show is that the learners had not assumed the collaboration and participation patterns they experienced within their current dominant culture education were the only 'normal' ways to be-they were able to select other repertoires of practice within this learning context. Clearly illustrated is need for teachers and other educators to construct deep understandings related to learners who are not from dominant cultural groups. Equitable outcomes for the non-dominant learners depend on recognition of interactions which differ from those considered normal within a dominant world view. As Civil (2016) writes, "we need to gain a better understanding of the participation structures, particularly in non-dominant communities" (p. 56). 